\title{
Study on Bank Cooperation Risk under the Background of Financial Opening and Cooperation in Southeast Asia
}

\author{
-A Case of Study of Laos
}

\author{
Ping Yang \\ Business School \\ Yunnan University of Finance and Economics \\ Kunming, China \\ 928915449@qq.com
}

\begin{abstract}
Laos became a important cooperative partner under the One Belt And One Road (OBOR) strategy based on the good -neighborliness and friendship. In this paper, through the framework of bank system in Laos, analyzed the existing problems in financial opening and cooperation between China and Laos.
\end{abstract}

Keywords-bank cooperation risk; financial opening and cooperation; Laos.

\section{INTRODUCTION}

In January 2016, Laos released the "eighth five-year" plan, the ten-year strategy and the fifteen-year vision plan for social development with the purpose of planning to become a middle-income country by 2030 . At present, 53 countries have invested in Laos. As the first largest investor in Laos, China has invested over US\$6.6 billion in terms of mineral, electricity, agriculture, service industries, etc. Laos' Special Economic Zone has attracted more than 160 Chinese companies to invest in the country with a registered amount of US $\$ 1.55$ billion, accounting for $23 \%$ of the total investment of the Special Economic Zone. Among them, industrial investment accounted for $38 \%$, trade and investment accounted for $38 \%$, and service sector investment accounted for $24 \%$ [1].

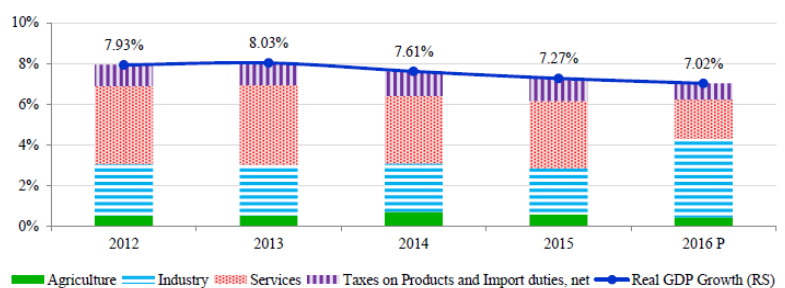

Fig. 1. Laos' GDP from 2012 to 2016

(Data from: Lao Statistics Bureau, Ministry of Planning and Investment)

Because of the gap between China and Laos, China imports primary products such as agricultural products, energy minerals and other primary products from Laos, while the exports to Laos are mainly manufactured products such as mechanical and electrical products and consumer goods. Among them, Yunnan is the only province that China borders Laos, and Laos is also the main land access to enter the Chinese market. From 2004 to 2013, the total volume of trade between Yunnan and Laos increased from about US\$30 million to US\$1.94 billion, with an average annual growth rate of $46.5 \%$ [2]. Yunnan's investment in Laos accounts for $26.4 \%$ of the real total foreign investment in the province. In this regard, Yunnan's investment in Laos has gradually improved the infrastructure conditions and investment environment of Laos.

\section{The Current Situation of LaOs' Banking}

Laos' legal tender is KIP, which is freely convertible and used in the market with the US dollar and the Thai baht. RMB can be exchanged and used in the economic zone of northern Laos.

\section{A. The Framework of the Banking System has been Basically Formed}

At present, the pattern of Laos' financial system has developed from single People's Bank to central bank and commercial bank, the coexistence of banks and non-bank financial institutions and insurance institutions, from the vertical allocation of pure funds to the indirect financing between banks, and the coexistence of money market and capital market.

Financial instruments have developed from simple credit instruments to multiple financing hedge tools such as treasury bonds, stocks, bonds, funds, insurance, etc. Financial markets are also developing towards breadth and depth. Since 1997, Laos has also opened the world's leading express remittance Western Union.

\section{B. Laos is Relatively Loose in Foreign Exchange Management}

Relatively loose exchange control creates a better environment for foreign investors. However, banks have fewer

*Corresponding author 
assets, the operation mode and the types of financial business are still relatively simple, the individual credit system has not been established, the foreign exchange reserves are less, the foreign payment capacity is limited and the foreign exchange system is relatively fragile.

\section{The Level of Financial Legal System is Backward}

The coordination between Laos' financial laws and China's legal system is poor. The debt default risk is high, the laws and regulations formulated are lack of clarity and guidance, the contents of the laws are conflicting, and the efficiency of the financial and judicial institutions is low. The rights of law enforcement organs are over-concentrated and they have the phenomenon of corruption.

\section{The Prospect of Financial Opening and Cooperation is Good}

In Laos' infrastructure projects, China's financial institutions can provide project financing, equity financing, syndicated loan and other services. In the resource development projects of China and Laos, China can provide not only investment banking, financing guarantee, factoring and $\mathrm{M} \& \mathrm{~A}$ loans, but also provide services for cross-border cash management, order financing, forfaiting and foreign exchange funds.

\section{LAOS’ BANKING SySTEM AND EXISTING PROBLEMS}

\section{A. Laos' Banking Institutions}

Laos implements two-level bank management system. The National Bank of Laos (central bank) is the regulatory department of commercial banks and other financial institutions, which is responsible for maintaining the stability of the currency value of the country, ensuring the security of the banking system, and promoting social and economic security. There are 176 financial institutions under the jurisdiction of the central bank in Laos, including: (1) 4 large state-owned commercial banks: Banque Pour Le Commerce Exterieur Lao Public (BCEL), Lao Development Bank (LDB), Agriculturel Promotion Bank (APB) and Nayobay Bank (NBB); (2) 16 private banks; (3) 3 joint venture banks (Lao China Bank Co., Ltd was a joint venture established by Fudian Bank and BCEL in 2014, Banque Franco-Lao Ltd

(BFL) , Lao Viet Bank (LVB) ); (4) 19 foreign branches. Laos' banks are relatively small and vulnerable. Moreover, the development of the securities and insurance industry is relatively backward, and the currency instability is more vulnerable to the impact of the financial crisis [3].

\section{B. The General Situation of Banking}

\section{- Development status and difficulties}

Owing to the late start of Laos' banking industry, and the blockade of western countries in the early stage, most commercial banks are more radical. In the course of operation, the scale and the growth rate of the deposit and loan are emphasized, and the index of capital adequacy ratio and the rate of return on capital equity are not fully taken into account. As a result, the increment of banking business is obvious. Furthermore, it also faces the embarrassing situation of high risk and low profit.[4] At the same time, due to the short time of Laos' reform, especially large state-owned commercial banks regard the goal of national distribution as the primary financial management target, and adopt the traditional financial management system with different levels of management, the power of financial management is extremely scattered, and it lacks the necessary supervision and management levels and constraints.

- Lack of independence in monetary policy

A large number of baht and US dollars are used for wage payment, shopping, repayment of loans and tuition fees. Because of the large circulation of foreign currency, the lack of timely policy adjustment, the lack of independence of the central bank and the lack of financial markets and financial instruments, the monetary policy of Laos is lack of independence and it is difficult to achieve effective policy goals.

- Suspension of licensing of financial institutions

In June 2, 2017, the central bank of Laos announced a suspension of the issuance of new financial institutions before February 28, 2019, during which the central bank will review the operating conditions of existing domestic financial institutions in Laos.

\section{Exchange Control}

In addition to obtaining the approval of the National Bank of Laos, any individual or legal person prohibits the direct use of foreign currency for sale or settlement in the circulation area of Laos. When a foreign currency holder is required to pay or settle accounts in Laos, he or she must go to a bank or institution that is allowed to convert foreign currency into foreign currency and then convert it into KIP [5]. The sale of foreign currency by individuals and legal persons must be carried out by banks or institutions approved by the Lao National Bank.

\section{The Development of China's Financial Institutions in Laos}

After the implementation of The Belt and Road Initiative, China and Laos have formed bilateral economic and trade cooperation in the field of multi dimension and multi situation. From 2011, Industrial and Commercial Bank of China (ICBC) and Bank of China (BOC) set up a branch in Laos. In 2013, Pacific Securities set up a joint venture securities company with Laos Information Enterprise and Agriculturel Promotion Bank [6]. In 2014, Fudian Bank and BCEL established the first joint venture bank with China and Laos. Among them, ICBC's Vientiane branch became the only RMB clearing bank approved by the Central Bank of Laos in 2012 (The first branch that obtained the business license of RMB clearing bank by host regulatory agencies)..

\section{E. Problems in the Management of the Central Bank of Laos}

\section{- The problem of information data}

The central bank's information data report and data management are difficult to coordinate among departments. As the relevant regulations are not sound, the departments and units that provide data are worried 
about legal problems, especially issues involving business secrets or personal privacy, as well as the subject of personnel, law, funds and equipment.

\section{- Weak monetary policy operation}

At present, Laos' monetary policy goals are to stabilize prices, promote economic growth, full employment, financial stability and balance of international payments. There is a conflict between the goals and it is reflected in the following aspects: When the number of unemployed is too large, monetary policy should achieve the goal of full employment by increasing the supply of money and expanding credit to stimulate investment demand and consumption demand, increase the number of employment and expand the scale of production. Meanwhile, the increase in demand will bring a certain degree of price rise.

- Lack of effective coordination between banks and financial institutions

The administrative functions of Laos are independent, so the information resources between the departments are not interconnected and the information is lagging behind. Multilateral supervision and cross regulation lead to regulatory conflicts and inefficient supervision. The coordination mechanism between banks, securities and insurance three supervisory departments is not yet perfect.

\section{F. Problems in the Management of Commercial Banks in Laos}

- The overall operation quality of the economy is not high

The overall quality of the macro-economic operation of the Laos is not high, which seriously restricts the development of commercial banks. A large number of enterprises have suffered losses and there have been a lot of bad assets in the banks.

- Risk management process is not standardized and it lacks comprehensive risk management consciousness

Because of the fierce market competition and high pressure of operating index, the decision-makers of some commercial banks have no consciousness of comprehensive risk management. The internal control system of the Commercial Bank of Laos cannot fully adapt to the needs of preventing and resolving financial risks. The reason is the rough and fuzzy of various rules and regulations, so that the business personnel at the grass-roots level cannot be operated and implemented.

- Lack of an effective risk analysis system

The technology of risk analysis is backward. In terms of mathematical methods such as mathematical statistics and financial engineering, there is a big gap compared with advanced international banks. Risk identification, measurement, monitoring and other risk management work are not scientific enough.
- The instability of macro financial policy

For a long time, the national economy of Laos has been in an unfavorable environment of expansion, contraction, re-expansion and further tightening. When the economy is overheated, the bank is bound to use the loan scale blindly from its own interests to get the loan scale of the next year, so that some enterprises with low benefit will take advantage of this opportunity and even use the illegal means to collect the loan of the bank.

- Administrative intervention of governments at all levels to commercial banks

Under the current economic system, the functions of government and enterprise at various levels are mixed in a whole. They are both chief executives of administrative affairs and direct organization and command of economic activities as representatives of property owners. In the course of operation, it is inevitably interfered by local governments and relevant departments, including: (1) They force banks to increase loans to businesses that are losing money or being on the verge of collapse, so as to maintain business survival and local taxes [7]; (2) Owing to there is no strict project feasibility study, blind distribution and duplication of construction, they force the banks to raise funds and lead to more investment but less recovery and slower turnover under the strong impulse to develop the local economy. Short term loans become long term, long-term loans are fixed, and credit funds are financially-oriented.

- The modern enterprise system has not been perfected

The lack of the system is a serious threat to the security of the bank's assets. Some localities and enterprises regard the transformation process as an opportunity to unload bank debts. They have many tactics and this poses a serious threat to bank assets.

- The relevant laws are not perfect

The basic framework of the national financial legal system of Laos has been formed, but various laws remain in the basic framework stage, and the relevant rules, supplementary regulations and operation norms are not perfect, and the risk management of commercial banks still lacks relevant laws. Financial intermediaries such as accounting firms, law firms, financial information technology related companies and other financial information management consulting companies have not formed a certain scale, which is not conducive to the formation of comprehensive, fair, timely and accurate market information [8].

\section{CONCLUSION}

The financial system of Laos is relatively backward compared with other countries in Southeast Asia. (1) Laos has not established a relatively complete central banking system. Moreover, modern settlement and payment system, foreign exchange reserve management system, electronic check 
system and data center have made slow progress. (2) The banking business in Laos has a small area of involvement. The development of the banking industry is lagging behind, and its support for investment is limited. About $50 \%$ of bank assets and $90 \%$ of bank deposits are concentrated in the capital Vientiane, so the level of regional development is uneven. (3) The exchange rate of currency fluctuates greatly. KIP has a complex trend toward the US dollar and the Thai baht, and its fluctuation is frequent. In addition, foreign currency settlement procedures are cumbersome, foreign currency transactions or settlement must be conducted to designated banks or institutions without using border economic cooperation. (4) The enterprise's project financing is difficult. The enterprise's project financing is difficult, while China's domestic banks have more loan procedures for overseas projects, so it is difficult for enterprises to obtain credit support from the local banks of Laos and domestic banks in China. (5) Financial related legislative and regulatory processes are slow, and the protection of investment and joint venture in Laos is low.

In the process of promoting investment or joint venture projects in Laos, the shortcomings of the Laos' financial system, especially the lag and difficulties in the legal aspects, should be fully taken into account, the necessary supplement should be carried out through consultation between the two parties in policy implementation and supervision, and the lack of Laos' financial law should be supplemented through the terms of the two parties. In particular, the special economic zones and the exclusive economic zones can be used as pilot reforms to promote the Laos' financial reform and legislative process, so as to promote the cooperation will and openness of
Laos to China, especially Yunnan, through the optimization and upgrading of regional cooperation.

\section{ACKNOWLEDGMENT}

First of all, I would like to thanks our college and YUFE, to provide the opportunity to me for research in Laos' economics and finance. Secondly, I must thank for professor Zhu Li who gave me many research material and helped me with the paper writing. Sincerely thanks all the friends who helped me during this research.

\section{REFERENCES}

[1] Wenyi Wang, Yongchang He, Hongzhou Wang "Obstacles and prospects for monetary and financial cooperation in southeast Asia", Squawk Box, vol. 18, 2016, pp.181.

[2] Shunda Kong," Risk management and regulatory development of commercial Banks in Laos”, Yunnan University,May,2015.

[3] Rajan,G.Raghuam.The past and future of commercial bank. Journal of money, credit, and banking, PART 2,VOL.30. NO.3.AUGUST 1998.

[4] Jinghua Guo, " the risk and management of liquidity of commercial Banks in Laos", 《Journal of Central University of Finance and Economics》, vol. 18, 2000.

[5] Ping Kan, 'Laos and China yunnan sub-regional economic cooperation study", Phd thesis, Yunnan Normal University, May,2016.

[6] Pathammayo Latchana, "Comparative analysis on financial management systems of commercial Banks in China and Laos", The financial times, vol. 2,2016,pp.55-56.

[7] Weilai Kang, "Study on the reform of state-owned commercial Banks in Laos", master's thesis, Jilin University, July ,2007.

[8] Gaiou Bu, "Neighboring Economies、 FDI and Economic development in Laos"”, Phd thesis, East China Normal University,April,2013. 